\title{
Cross-Fencing on Private US Rangelands: Financial Costs and Producer Risks
}

\section{By Kevin Bracy Knight, Theodore P. Toombs, and Justin D. Derner}

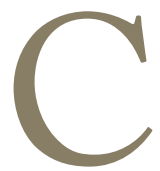

ross-fencing to subdivide large pastures into smaller ones commonly is done to intensify grazing management and achieve more uniform livestock distribution. Although subdividing pastures does not increase forage production, ${ }^{1}$ the benefits to producers include higher utilization of formerly underutilized forage at distances greater than one mile from water, as grazing intensity decreases with distance from water. ${ }^{2,3}$ As a result of this greater availability of forage, many producers are able to increase livestock numbers and stocking rate and enhance grazing efficiency ${ }^{4}$ and profitability. ${ }^{5}$ Payments for cross-fencing can be provided to private landowners through the US Department of Agriculture Natural Resources Conservation Service (USDA-NRCS), the federal agency responsible for administering Farm Bill programs. For example, over 5,700 miles of cross-fencing was erected from 2004 to 2007 on private rangelands in the western United States with financial assistance from the Environmental Quality Incentives Program (EQIP). ${ }^{6}$ In the past, NRCS provided cost-share based on the actual cost to producers (typically 50\%), whereas more recently, they shifted to a direct payment (based on averaged costs) to producers no matter what their actual cost. This shift results in variable cost-share rates, depending on the producer's actual cost to erect the fence. The cost of fencing estimated in our research reflects this new, direct payment system.

The installation of cross-fences can have direct and indirect ecological impacts. Direct impacts include: 1) wildlife mortality through collisions, 2) facilitation of predation, and 3) fragmentation of habitats for area-sensitive birds. ${ }^{7-10}$ Indirect impacts include reductions in vegetation heterogeneity (structure and composition ${ }^{11}$ ) that result from more uniform livestock distribution. Although conservation organizations and agencies often are concerned with the ecological costs of cross-fencing, private landowners also must consider financial costs when deciding whether to intensify grazing management. Clearly, there are immediate (short-term) costs associated with the materials and labor for erection of cross-fences, but more fencing also creates additional long-term maintenance and repair costs. Here, we evaluate these short- and long-term financial costs for crossfencing a hypothetical 10,240-acre pasture of northern mixed-grass prairie in Montana into 16 square, even-sized 640-acre pastures, with and without financial assistance from EQIP. Our goal is to assess whether adding crossfencing is a sound, long-term financial decision by testing whether the producer benefits of cross-fencing outweigh producer and public financial and ecological costs. In addition, we estimate the increase in stocking rate needed to compensate for the costs associated with installation and maintenance.

\section{Assumptions and Calculations}

The following assumptions were made for our hypothetical 10,240-acre pasture in Montana:

1) it currently is a single pasture with perimeter fence;

2) topographical constraints are not present to prevent cross-fencing into 16 even-sized 640-acre pastures;

3) all cross-fences are four-strand barbed wire;

4) the initial installation and labor cost of four-strand barbed wire is $\$ 8,290 / \mathrm{mile}^{12}$

5) maintenance costs are $8 \%$ annually of initial installation and labor; ${ }^{13,14}$

6) EQIP payments for cross-fencing are $\$ 6,230$ per mile; ${ }^{15}$

7) the current stocking rate is the NRCS recommended moderate level (0.45 animal unit months or AUM/ acre);

8) there are no concerns regarding rangeland health for this pasture;

9) water facilities (pipelines, tanks) are sufficient and will not need to be added;

10) no change in plant or animal productivity of the pasture would occur with the subdivision into more pastures ${ }^{1}$ over the 20-year evaluation period (this was assumed so 
that we could later test what increased profits would be needed to keep the ranch sustainable);

11) the baseline hypothetical ranch is operating at a breakeven point covering all current fencing maintenance costs (thus accruing no interest over the years);

12) the baseline ranch, operating at a break-even state, is able to pay all fencing maintenance costs (other models were normalized to reflect that annual revenue); and

13) whenever possible, costs incurred will be paid for in the same year, thereby creating no interest debt.

First, we calculated the financial costs of cross-fencing the pasture. We then evaluated the costs of erecting the cross-fencing with and without EQIP payments against the single pasture baseline condition. Our model assumed that a new fencing venture would be debt-financed through a line of credit and that any debt incurred throughout a given year or carried over from a previous year would accrue annual interest at a consistent $6 \%$. Our calculations were modeled over a 20 -year period because this is the estimated useful lifespan of barbed wire fence. ${ }^{13,14}$ We assumed a $7 \%$ discount rate based on a $4 \%$ risk premium on the value of a 10-year treasury note at $2.85 \%$ (November, 2010) to estimate the net present value (NPV).

\section{Initial Costs}

Producers often weigh the initial costs of purchasing new infrastructure in a business with little thought towards longterm maintenance. To subdivide the baseline pasture into 16 , 640-acre pastures, a minimum of 24 miles of new fence would be needed at $\$ 8,290 /$ mile, or a total of $\$ 198,960$. With an EQIP payment of $\$ 151,680$ ( $\$ 6,230 /$ mile), this leaves a net cost for the producer of $\$ 47,280$, or about $25 \%$ of the total cost (Table 1).

\section{Long-Term Costs}

Without the new cross-fencing, our producer's annual maintenance costs were $\$ 10,611$. Subdividing the pasture into 16 , 640-acre pastures resulted in a total annual maintenance cost of $\$ 26,527$, an increase of $\$ 15,916$ annually. This resulted in a total cost increase of $\$ 318,320$ over the 20 -year life expectancy of the fence. Adding the cross-fencing will substantially increase interest debt to the producer at the end of the 20-year period, due to the financing of both the initial costs and the higher total maintenance costs. Even

Table 1. Initial cost of cross-fencing a single 10,240 -acre pasture to 16,640 -acre pastures with and without Environmental Quality Incentives Program (EQIP)

\begin{tabular}{|l|c|c|}
\hline Variable & Without EQIP & With EQIP \\
\hline Miles of new cross-fence & 24 & 24 \\
\hline Total cost of cross-fence & $\$ 198,960$ & $\$ 198,960$ \\
\hline EQIP Payment & $\$ 0$ & $\$ 151,680$ \\
\hline Landowner costs & $\$ 198,960$ & $\$ 47,280$ \\
\hline
\end{tabular}

with EQIP payments to offset some of the initial costs, a producer is left with a net increase of $\$ 802,992$ of actual debt from accrued interest and continuing maintenance costs (Table 2). We normalized the net present value (NPV) for each scenario based on the assumption that the baseline ranch operated at break-even level, having an NPV of 0, to minimize the challenges of comparison. From this, we observed a NPV for additional cross-fencing to be $-\$ 833,932$ and $-\$ 450,891$, respectively, for adding fencing without or with EQIP support.

\section{The Need for Increased Profit Places Pressure on the Land}

Our model shows how the high initial and continuing longterm costs of cross-fencing contribute to the need for increased profit to keep the ranch at the break-even point. Although initial costs are somewhat obvious, we show that long-term maintenance costs can contribute significantly to debt. If our hypothetical producer wishes to simply break even after a 20 -year period he would need to increase profits from his land substantially. Without any EQIP payment, our model predicts that an increase in annual profit of $\$ 33,708$ ( $\$ 3.29 /$ acre) would be needed to cover short- and long-term costs plus interest over 20 years. With EQIP, a net increase in annual profit of $\$ 21,410$ (\$2.09/acre) would still be needed to break even in 20 years.

To understand how the need for increased profit might place more grazing pressure on the land, we estimated the increase in stocking rate that would be needed to result in the profits above. We calculated baseline beef production at 39.2 pounds/acre using the NRCS recommended stocking rate $(0.45 \mathrm{AUM} / \mathrm{acre})$ and the relationship between stocking rate and beef production for northern mixed grass prairie. ${ }^{16}$ Assuming grazing is by yearling steers, the selling price of these animals off the rangeland in the fall is $\$ 1 /$ pound live weight, and total expense for grazing animals is $44 \%$ of gross income for rangeland in excellent condition, ${ }^{5}$ we estimate that beef production would need to increase by 3.7 and 5.9 pounds/acre to accomplish the net increase in annual profit to break even with and without EQIP, respectively. Using the beef production values needed (42.9 pounds/acre with EQIP, 45.1 pounds/acre without EQIP), and the relationship between beef production and stocking rates, ${ }^{16}$ the stocking rates to accomplish this increased beef production would be $0.49 \mathrm{AUM} /$ acre with EQIP, and 0.52 AUM/ acre without EQIP. These values represent an increase in stocking rate for the entire ranch for the next 20 years of $9 \%$ and $16 \%$ with EQIP and without EQIP payments, respectively.

\section{Conclusions}

Installing cross-fencing creates significant short- and longterm costs for producers. Although initial construction and materials costs can be offset partially with EQIP payments, long-term maintenance costs are a continuing burden carried solely by the producer into the future. Cross-fencing 
Table 2. Long-term cost of cross-fencing a single 10,240-acre pasture to 16, 640-acre pastures with and without Environmental Quality Incentives Program (EQIP)

\begin{tabular}{|l|c|c|c|}
\hline Variable & Baseline & Cross-fencing without EQIP & Cross-fencing with EQIP \\
\hline Initial cost of cross-fence & $\$ 0$ & $\$ 198,960$ & $\$ 47,280$ \\
\hline Maintenance costs & $\$ 212,220$ & $\$ 530,540$ & $\$ 530,540$ \\
\hline Interest costs & $\$ 0$ & $\$ 775,894$ & $\$ 445,862$ \\
\hline Total costs & $\$ 212,220$ & $\$ 1,505,394$ & $\$ 1,023,682$ \\
\hline Normalized NPV* & $\$ 0$ & $-\$ 833,932$ & $-\$ 450,891$ \\
\hline * Normalized NPV (net present value) is a calculation of NPV of each change scenario relative to the baseline scenario.
\end{tabular}

increases long-term overhead costs, with or without EQIP payments.

Cross-fencing is implemented largely to improve livestock distribution and intensify grazing management. Our simple economic analyses show that producers will need to modify management strategies to increase economic returns to pay off initial costs, as well as increased annual maintenance and the debt to finance both. One potential modification for producers is to implement higher stocking rates to increase profitability. ${ }^{5}$ Here, we estimate increases of $9-16 \%$ in stocking rate for the next 20 years to maintain break-even conditions for the ranch associated with the increased costs attributed to installation and maintenance of the cross-fencing. Although increasing stocking rates above the recommended levels might have short-term economic advantages, ${ }^{17}$ long-term sustainability of the rangeland resource can be compromised in some rangeland systems ${ }^{5}$ (but see Hart and Ashby's work on grazing intensities, vegetation, and heifer gains ${ }^{18}$ ).

Availability of EQIP payments might facilitate intensification of grazing management by encouraging the installation of cross-fencing that otherwise might not be economically feasible for producers. Our findings show that the increased financial costs associated with this decision could lead to long-term debt. Thus, EQIP payments, although well intended, might inadvertently increase producer financial risk by increasing long-term overhead costs and encouraging higher stocking rates.

Furthermore, our analysis highlights the tradeoff between two types of ecosystem services produced from rangelands, livestock production and biodiversity (e.g., wildlife habitat maintenance). Because wildlife habitat maintenance typically is not a source of producer income, it often is overlooked when making financial decisions, such as cross-fencing. However, the emergence of market-based or government payments for ecosystem services points to the need to encourage producers to look more carefully at the financial risks, tradeoffs, and opportunities associated with optimizing the two services rather than maximizing one or the other.

\section{References}

1. Briske, D. D., J. D. Derner, J. R. Brown, S. D. Fuhlendorf, W. R. Teague, K. M. Havstad, R. L. Gillen, A. J. Ash,
AND W. D. Willms. 2008. Rotational grazing on rangelands: reconciliation of perception and experimental evidence. Rangeland Ecology E Management 61:3-17.

2. Adler, P. B., And S. A. Hall. 2005. The development of forage production and utilization gradients around livestock watering points. Landscape Ecology 20:319-333.

3. Sasaki, T., T. Okayasu, U. Jamsran, and K. Takeuchi. 2008. Threshold changes in vegetation along a grazing gradient in Mongolian rangelands. Journal of Ecology 96:145-154.

4. Smart, A. J., J. D. Derner, J. R. Hendrickson, R. L. Gillen, B. H. Dunn, E. M. Mousel, P. S. Johnson, R. N. Gates, K. K. Sedivec, K. R. Harmoney, J. D. Volesky, and K. C. Olson. 2010. Effects of grazing pressure on efficiency of grazing on North American Great Plains rangelands. Rangeland Ecology \& Management 63:397-406.

5. Dunn, B. H., A. J. Smart, R. N. Gates, P. S. Johnson, M. K. Beutler, M. A. Diersen, and L. L. Janssen. 2010. Long-term production and profitability from grazing cattle in the Northern Mixed Grass Prairie. Rangeland Ecology E Management 63:233-242.

6. Toombs, T. P., and M. G. Roberts. 2009. Are natural resources conservation range management investments working at cross-purposes with wildlife habitat goals on western United States rangelands? Rangeland Ecology E Management 62:351-355.

7. Connelly, J. W., M. A. Schroeder, A. R. Sands, and C. E. Braun. 2000. Guidelines to manage sage grouse populations and their habitats. Wildlife Society Bulletin 28:967-985.

8. Freilich, J. E., J. M. Emlen, J. J. Duda, D. C. Freeman, And P. J. Cafaro. 2003. Ecological effects of ranching: a six-point critique. BioScience 53:759-765.

9. Patten, M. A., D. H. Wolfe, E. Shochat, and S. K. Sherrod. 2005. Habitat fragmentation, rapid evolution and population persistence. Evolutionary Ecology Research 7:235249.

10. Wolfe, D. H., M. A. Patten, E. Shochat, C. L. Pruett, and S. Sherrod. 2007. Causes and patterns of mortality in Lesser Prairie-Chickens Tympanuchus pallidicinctus and implications for management. Wildlife Biology (Suppl. 1) 13:95104.

11. Fuhlendorf, S. D., And D. M. Engle. 2001. Restoring heterogeneity on rangelands: ecosystem management based on evolutionary grazing patterns. BioScience 51:625-632.

12. Montana NRCS. 2009. Cost of applying conservation practices. Available at: http://efotg.nrcs.usda.gov/references/ public/MT/2010_Cost_List.pdf. Accessed 15 June 2010. 
13. Broussard, K. R., and R. N. Gates. 1988. Comparative costs for fence construction. Rangelands 10:224-226.

14. Iowa State University Extension. 2005. Estimated costs for livestock fencing. Iowa State University, University Extension FM 1855. Available at http://www.extension.iastate.edu/ Publications/FM1855.pdf. Accessed 9 March 2010.

15. MT NRCS Practice Payment Schedule. 2008. Available at: http://efotg.nrcs.usda.gov/references/public/MT/EQIP2010_ pps.pdf. Accessed 9 June 2010.

16. Derner, J. D., R. H. Hart, M. A. Smith, and J.W. Waggoner, JR. 2008. Long-term cattle gain responses to stocking rate and grazing systems in northern mixed grass-prairie. LivestockScience 117:60-69.

17. Manley, W. A., R. H. Hart, M. J. Samuel, M. A. Smith, J. W. Waggoner, JR., And J. T. Manley. 1997. Vegetation, cattle, and economic responses to grazing strategies and pressures. Journal of Range Management 50:638-646.

18. Hart, R. H., and M. M. Ashby. 1998. Grazing intensities, vegetation, and heifer gains: 55 years on shortgrass. Journal of Range Management 51:392-398.

Authors are Economist and Private Consultant (Bracy Knight) and Director, Center for Conservation Incentives, Rocky Mountain Region, Environmental Defense Fund, Rocky Mountain Regional Office, Boulder, CO 80304, USA, ttoombs@edf.org (Toombs); and Research Rangeland Management Specialist, US Department of Agriculture-Agricultural Research Service (USDA-ARS), Cheyenne, WY 82009, USA (Derner). 